\title{
Seasonal Incidence, Comparative Field Efficacy of Chemical Insecticides and their Economics for Management Brinjal Shoot and Fruit Borer Leucinodes orbanalis (guenee)
}

\author{
Saurabh Kumar Tyagi, Sharanappa* and Ashwani Kumar \\ Department of Entomology, SHIATS, Naini, Allahabad (211007) U.P., India \\ *Corresponding author
}

\begin{abstract}
A B S T R A C T
A field experiment was conducted during Kharif 2015-16 in central research farm of Sam Higginbottom Institute of Agriculture Technology and Sciences, Allahabad to evaluate the

\section{Keywords}

Cost benefit ratio, Efficacy, Shoot and fruit borer, Per cent larval population

\section{Article Info}

Accepted:

04 February 2019

Available Online:

10 March 2019 field efficacy of certain chemicals against shoot and fruit borer on Brinjal. The occurrence of Shoot and Fruit Borer commenced from $34^{\text {th }}$ standard week (August fourth week) with an average population of 0.90 larvae/plant. The shoot and fruit borer population increased and gradually reached its peak level of 6.56 larvae/plant at $40^{\text {th }}$ standard week (October first week). There after declined trend was observed as temperature increased and temperature between $30-37^{\circ} \mathrm{C}$ favoured the multiplication of shoot and fruit borer. The per cent population reduction of Brinjal shoot and fruit borer on third, seventh and fourteenth days after spraying revealed that Chlorantroniliprole found superior over all the treatments followed by Spinosad and Emamectin benzoate. Highest reduction in larval population (74.02\%) was observed with Chlorantroniliprole. Minimum shoot damage of $6.72 \%$ and highest yield of $255.78 \mathrm{q} / \mathrm{ha}$ was registered in Chlorantroniliprole. Highest Cost benefit ratio was recorded in Chlorantroniliprole (1:5.32) followed by Spinosad (1:4.32), Emamectin benzoate (1:5.10), Deltamethrin (1:4.24), Quinalphos (1:3.96), Carbosulfan (1:3.88) and Neem oil (1:3.71).
\end{abstract}

\section{Introduction}

Brinjal is an important solanaceous vegetable of our country. In hot wet monsoon season when other vegetables are in short supply, it is practically the only vegetable that is available at an affordable price for rural and urban poor. Brinjal is often infested by a plethora of insect pests among which shoot and fruit borer is the most destructive and active throughout the year, particularly under high temperature and humid conditions causing great damage. The larvae bore into the young axillary shoots, causing wilting and enter the fruits unobtrusively, with small enhanced holes plugged with excreta. The presence of holes and larval excreta in tunnels made in the fruit favour the development of secondary infection by microorganisms as well as the entry of insect scavengers resulting in fruit decay (Kalawate and Dethe, 2012). Holes made by the first and second instar larvae partially heal 
up with the increase in fruit size and there will be reduction in vitamin $\mathrm{C}$ content to an extent of 68 per cent in the infested fruits. The yield loss due to the pest is to the extent of 70 to 92 per cent (Ayyanar et al., 2014).

\section{Materials and Methods}

The field trial was laid out at the university farm in randomized block design with eight treatments including an untreated control each with three replications. The "Banarasi Round" variety of Brinjal was used and a healthy crop was raised by following all the recommended agronomical practices. The plot size was $2 \mathrm{~m} \mathrm{x}$ $1 \mathrm{~m}$ and the spacing between rows and plants was maintained at 60 and $45 \mathrm{~cm}$, respectively. Sprays were initiated on reaching 4 to 5 larvae per plant and shoot and fruit damage by the borer and repeated three times during the crop season as and when the shoot damage exceeded 10 to 20 percent. Spraying was done with the help of a knapsack sprayer. Seasonal incidence also observed in separate three plots of size $2 \mathrm{~m} \times 1 \mathrm{~m}$ at different places within university farm. Observations were taken daily to observe incidence of key pest of Brinjal.

The present investigation was carried out by conducting the field experiment during Kharif 2015 at the Central research farm of Department of Entomology, SHUATS, Allahabad, Uttar Pradesh. The experimental material for this study consisted of Banarsi round-II variety of Brinjal and planted in two separate contiguous blocks in Randomized Block Design with seven treatments viz., Chlorantroniliprole 18.5 SC $\quad(0.2 \mathrm{ml} / \mathrm{l})$, Emamectin benzoate $5 \mathrm{SG}(0.3 \mathrm{~g} / \mathrm{l})$, Spinosad $45 \mathrm{SC}(0.2 \mathrm{ml} / \mathrm{l})$ Quinalphos $25 \mathrm{EC}(2 \mathrm{ml} / \mathrm{l})$, Deltamethrin 25 EC $(0.1 \mathrm{ml} / \mathrm{l})$, Carbosulfan 20 EC $(1.5 \mathrm{ml} / \mathrm{l})$ and Neem oil $0.3 \mathrm{EC}(5 \mathrm{ml} / \mathrm{l})$ including an untreated control with three replications by following all the recommended package of practices to raise the healthy crop. The plot size of $2 \mathrm{~m} \times 1 \mathrm{~m}$ and spacing of $60 \mathrm{x}$
$45 \mathrm{~cm}$ between rows and plants was maintained. Spraying was done with the help of a knapsack sprayer. Chemicals were sprayed just after initiation of insect and repeated thrice at 15 days interval.

\section{Preparation of insecticidal solution}

The insecticidal spray solution of desired concentration as per treatment will be freshly prepared every time at the time of experimentation just before the start of spraying operations.

The spray solution of desired concentration prepared by adopting the following formula-

$V=\frac{C \times A}{\% a \cdot i .}$

Where,

$\mathrm{V}=$ Volume/ Weight of commercial insecticide in $\mathrm{ml}$ or gm.

$\mathrm{C}=$ Concentration required.

$\mathrm{A}=$ Volume of solution to be prepared.

$\%$ a.i. $=$ Percentage active ingredient

\section{Efficacy of treatments}

The population of shoot and fruit borer was recorded before one day before spraying and on $3^{\text {rd }}, 7^{\text {th }}$ and $14^{\text {th }}$ day after insecticidal application. The population of shoot and fruit borer was recorded from five randomly selected and tagged plants from each plot.

\section{Percent shoot infestation}

Observations were recorded on the number of infested shoots in each plot a day before spray and $3^{\text {rd }}, 7^{\text {th }}$ and $14^{\text {th }}$ days after spraying on selected plants. The per cent shoot damage was worked syntax using the formula on number basis. 
Percent

damaged $=\frac{\text { Number of infected shoots }}{\text { Total number of shoots }} \times 100$

\section{Percent fruit infestation}

Observations were recorded on the number of infested fruits and total number of marketable fruits on selected plants in a plot picking wise. The per cent fruit damage was worked out by using the formula on number basis.

Percent fruit Damaged

$=\frac{\text { Number of damaged fruits }}{\text { Total number of fruits }} \times 100$

The data of maximum and minimum temperature, relative humidity, rainfall, sunshine hours and wind velocity were collected from the university meteorological observatory which is located in Agro metrology Department. They were correlated with the population of insect pests.

\section{Benefit Cost Ratio}

Gross returns were calculated by multiplying total yield with the market price of the produce. Cost Benefit Ratio was calculated by following formula.

$$
C: B=\frac{\text { Net returns }}{\text { Cost of treatments }} \times 100
$$

\section{Results and Discussion}

Studies on the incidence of shoot and fruit borer population with weather parameters given in Table 1 . The occurrence of shoot and fruit borer was commenced from $34^{\text {th }}$ standard week (August fourth week) with an average $0.90 \%$ temperature favoured the multiplication of shoot and fruit borer whereas decline of maximum and minimum temperature lead to decline of the shoot and fruit borer population. Similar findings have been reported by Gangwar and Singh (2014). The incidence of pest population was recorded on shoots as well as on fruits. Maximum numbers of larvae were recorded in the $41^{\text {st }}$ standard week. Shukla and Khatri (2010) reported shoot borer infestation increased considerably in the month of October and November and decreased in subsequent weeks of December.

\section{Efficacy of treatments}

The data on the percent shoot infestation of first spray revealed that all the chemical treatments were significantly superior over control (Table 2). Among the treatments lowest percent infestation of shoot and fruit borer was recorded in Chlorantroniliprole (6.72) which was statistically on par with Emamectin benzoate (10.41), Spinosad (12.29), Quinalphos (13.18), Deltamrthrin (13.73), Carbosulfan (18.43) and Neem oil (23.95) respectively.

The data on the percent fruit infestation of shoot and fruit borer on second and third spray overall mean revealed that all the treatments were significantly superior over control. Among the treatments lowest percent infestation of fruit was recorded in Chlorantroniliprole (6.62\%) followed by Emamectin benzoate (9.18\%), Spinosad (13.17\%) Quinalphos (14.36\%), Deltamethrin $(16.06 \%)$, Carbosulfan $(20.27 \%)$ and Neem oil $(26.01 \%)$.

This is due to the remarkably favourable toxicity profile of Chlorantroniliprole a valuable option for insecticide resistance management and thus a safety study tool for key beneficial arthropods, and thus kills the pest by paralyzing them at a faster rate and due to this reason fruit infestation was found to be minimum.

Since, the insect population was minimum as such the plants were healthy and gave higher number of fruits. 
This treatment recorded the maximum return and higher cost benefit ratio. Similar results were reported by Kalawate and Dethe (2012), Das et al., (2014) and Sinha et al., (2012).

\section{Cost benefit ratio}

The yields among the treatments were significant. The highest yield was recorded in $\mathrm{T}_{1}$ Chlorantroniliprole $(255.78 \mathrm{q} / \mathrm{ha})$ followed by $\mathrm{T}_{3}$ Emamectin benzoate ( $\left.239.53 \mathrm{q} / \mathrm{ha}\right), \mathrm{T}_{2}$ Spinosad (202.41 q/ha), $\mathrm{T}_{4}$ Deltamethrin (193.24 q/ha), T5 Quinalphos (186.73 q/ha), $\mathrm{T}_{6}$ Carbosulfan (178.43 q/ha) and $T_{7}$ Neem oil $(169.67 \mathrm{q} / \mathrm{ha})$ as compared to control $\mathrm{T}_{\mathrm{o}}$ $(90.32 \mathrm{q} / \mathrm{ha})$. Among the treatments studied the best and most economical treatment was
$\mathrm{T}_{1}$ Chlorantroniliprole (1:5.32) followed by $\mathrm{T}_{3}$ (1:5.10), $\mathrm{T}_{2}$ (1:432), $\mathrm{T}_{4}(1: 4.24), \mathrm{T}_{5}$ (1:3.96), $\mathrm{T}_{6}$ (1:3.88), $\mathrm{T}_{7}$ (1:3.71) as compared to control $\mathrm{T}_{\mathrm{o}}$ (1:2.02). The highest yield and cost benefit ratio was recorded in $\mathrm{T}_{1}$ Chlorantroniliprole (255.78q/ha and 1:5.32) (Table 3 and 4). This result is supported by Mishra (2011).

From the critical analysis of the present findings it can be concluded that shoot and fruit borer population on Brinjal increased with increasing maximum temperature and decreased with decline in maximum temperature, minimum temperature, morning and evening relative humidity and decreased with increasing maximum temperature above $35^{\circ} \mathrm{C}$, wind velocity and sunshine hours.

Table.1 Seasonal incidence of shoot and fruit borer of Brinjal during Kharif 2015

\begin{tabular}{|c|c|c|c|c|c|c|c|c|}
\hline \multirow{2}{*}{$\begin{array}{c}\text { Standard } \\
\text { week }\end{array}$} & \multirow{2}{*}{$\begin{array}{c}\text { No. of } \\
\text { larvae/plant }\end{array}$} & \multicolumn{2}{|c|}{ Temperature } & \multicolumn{2}{|c|}{ Humidity \% } & \multirow{2}{*}{$\begin{array}{c}\text { Rainfall } \\
(\mathbf{m m})\end{array}$} & \multirow{2}{*}{$\begin{array}{l}\text { Wind } \\
\text { velocity }\end{array}$} & \multirow{2}{*}{$\begin{array}{l}\text { Sunshine } \\
\text { (Hr./day) }\end{array}$} \\
\hline & & Max. & Min. & Morning & Evening & & & \\
\hline 29 week & 0.00 & 32.70 & 27.67 & 92.14 & 65.85 & 6.28 & 1.59 & 4.42 \\
\hline 30 week & 0.00 & 33.68 & 24.22 & 90.42 & 63.71 & 1.11 & 2.00 & 3.82 \\
\hline 31 week & 0.00 & 35.34 & 28.02 & 90.71 & 58.71 & 0.42 & 2.77 & 5.45 \\
\hline 32 week & 0.00 & 34.08 & 27.74 & 90.57 & 55.42 & 2.20 & 1.33 & 5.82 \\
\hline 33 week & 0.00 & 35.97 & 27.51 & 92.42 & 53.42 & 5.00 & 1.28 & 5.34 \\
\hline 34 week & 0.90 & 33.22 & 27.00 & 92.85 & 58.28 & 12.48 & 2.22 & 4.80 \\
\hline 35 week & 1.80 & 35.45 & 27.42 & 90.71 & 54.85 & 11.85 & 2.55 & 5.74 \\
\hline 36 week & 2.02 & 36.42 & 27.20 & 89.71 & 45.42 & 0.00 & 1.68 & 7.97 \\
\hline 37 week & 3.33 & 37.48 & 27.37 & 86.71 & 47.14 & 0.00 & 2.17 & 8.70 \\
\hline 38 week & 3.71 & 35.65 & 28.05 & 86.28 & 55.71 & 0.60 & 1.71 & 7.11 \\
\hline 39 week & 4.35 & 36.42 & 27.80 & 90.71 & 47.14 & 0.20 & 1.84 & 7.17 \\
\hline 40 week & 5.88 & 36.11 & 27.85 & 89.00 & 50.14 & 0.00 & 1.56 & 8.45 \\
\hline 41 week & 6.56 & 35.77 & 27.82 & 90.85 & 51.57 & 0.00 & 1.35 & 8.68 \\
\hline 42 week & 4.65 & 35.85 & 23.88 & 78.28 & 51.40 & 0.00 & 0.96 & 8.57 \\
\hline 43 week & 4.46 & 36.00 & 20.57 & 93.00 & 50.71 & 0.00 & 0.71 & 8.65 \\
\hline 44 week & 3.20 & 35.25 & 19.71 & 91.57 & 29.71 & 0.64 & 0.51 & 6.65 \\
\hline 45 week & 2.33 & 33.57 & 20.08 & 90.71 & 57.00 & 0.00 & 0.48 & 8.30 \\
\hline $\mathbf{r}$ & 0.829 & 0.375 & -0.622 & -0.256 & -0.630 & -0.444 & -0.681 & 0.411 \\
\hline $\mathbf{t}$ & 5.739 & 1.566 & -3.077 & -1.026 & -3.140 & -1.917 & -3.600 & 1.748 \\
\hline
\end{tabular}


Table.2 Field efficacy of chemicals against shoot and fruit borer on Brinjal

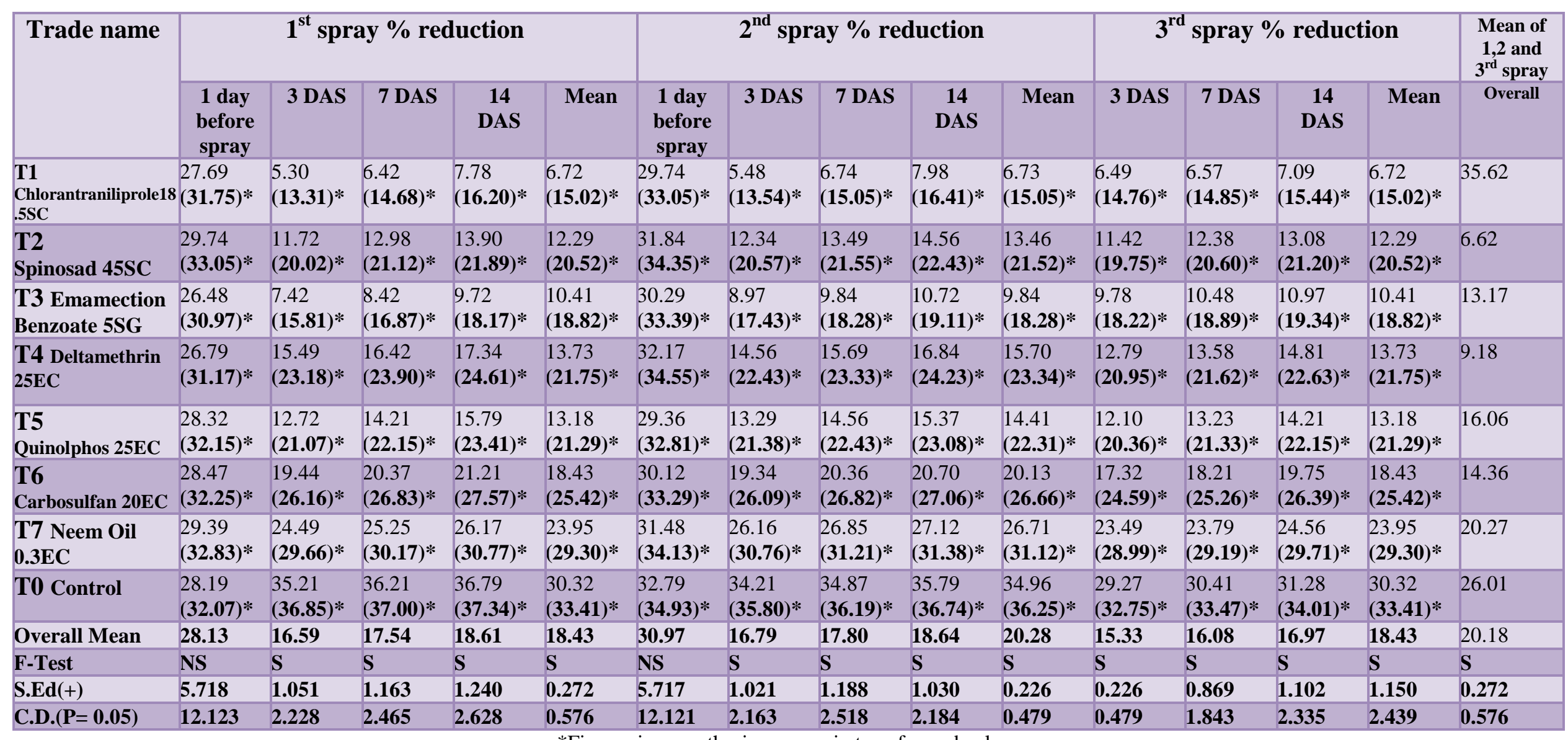

*Figures in parenthesis are arc sin transformed values 
Table.3 Economics of treatments

\begin{tabular}{|c|c|c|c|c|c|c|}
\hline $\begin{array}{l}\text { Sl. } \\
\text { No }\end{array}$ & Treatments & $\begin{array}{c}\text { Use of } \\
\text { chemical } 3 \\
\text { times } \\
\text { spray }\end{array}$ & $\begin{array}{c}\text { Cost of } \\
\text { Chemicals } \\
\text { (Rs.) }\end{array}$ & $\begin{array}{c}\text { Total } \\
\text { Cost of } \\
\text { Chemicals } \\
\text { (Rs.) }\end{array}$ & $\begin{array}{c}\text { Use of } 2 \\
\text { labours } \\
3 \text { time } \\
\text { spray }\end{array}$ & $\begin{array}{l}\text { Total cost of } \\
\text { Treatment } \\
\quad \text { (Rs.) }\end{array}$ \\
\hline 1 & $\begin{array}{l}\text { Chlorantraniliprole } \\
18.5 \mathrm{SC}\end{array}$ & $160 \mathrm{ml} / \mathrm{ha}$ & $\begin{array}{l}1916 \mathrm{Rs} \\
\text { /150ml }\end{array}$ & 2064 & 900 & 2964 \\
\hline 2 & Spinosad 45SC & $99 \mathrm{ml} / \mathrm{ha}$ & 13333 Rs /lit & 1320 & 900 & 2220 \\
\hline 3 & $\begin{array}{l}\text { Emamection } \\
\text { Benzoate 5SG }\end{array}$ & $150 \mathrm{gm} / \mathrm{ha}$ & 969 Rs $/ 100 g$ & 1454 & 900 & 2354 \\
\hline 4 & Deltamethrin 25EC & $50 \mathrm{ml} / \mathrm{ha}$. & $70 \mathrm{Rs} / 100 \mathrm{ml}$ & 50 & 900 & 950 \\
\hline 5 & Quinolphos 25EC & $1000 \mathrm{ml} / \mathrm{ha}$ & $405 \mathrm{Rs} / 250 \mathrm{ml}$ & 1620 & 900 & 2520 \\
\hline 6 & Carbosulfan 20EC & $750 \mathrm{ml} / \mathrm{ha}$ & $161 \mathrm{Rs} / 250 \mathrm{ml}$ & 483 & 900 & 1383 \\
\hline 7 & Neem Oil 0.3EC & $1.35 \mathrm{lit} / \mathrm{ha}$ & 170 Rs / lit & 230 & 900 & 1130 \\
\hline 8 & Control & - & - & - & - & - \\
\hline
\end{tabular}

Table. 4 Cost of cultivation

\begin{tabular}{|l|l|c|c|c|c|c|c|c|}
\hline $\begin{array}{l}\text { Sl. } \\
\text { No }\end{array}$ & \multicolumn{1}{|c|}{ Treatments } & $\begin{array}{c}\text { Yield of } \\
\mathbf{q} / \mathbf{h a}\end{array}$ & $\begin{array}{c}\text { Cost of } \\
\text { yield / } \\
\text { Rs/q }\end{array}$ & $\begin{array}{c}\text { Total } \\
\text { cost of } \\
\text { yield }\end{array}$ & $\begin{array}{c}\text { Common } \\
\text { cost }\end{array}$ & $\begin{array}{c}\text { Treatment } \\
\text { cost }\end{array}$ & $\begin{array}{c}\text { Total } \\
\text { cost }\end{array}$ & $\begin{array}{c}\text { C:B } \\
\text { ratio }\end{array}$ \\
\hline $\mathbf{1}$ & $\begin{array}{l}\text { Chlorantraniliprole } \\
\text { 18.5SC }\end{array}$ & 255.78 & 1000 & 255780 & 44538 & 2964 & 47502 & $1: 5.32$ \\
\hline $\mathbf{2}$ & Spinosad 45SC & 202.41 & 1000 & 202410 & 44538 & 2220 & 46758 & $1: 4.32$ \\
\hline $\mathbf{3}$ & $\begin{array}{l}\text { Emamection } \\
\text { Benzoate 5SG }\end{array}$ & 239.53 & 1000 & 239530 & 44538 & 2354 & 46892 & $1: 5.10$ \\
\hline $\mathbf{4}$ & Deltamethrin 25EC & 193.24 & 1000 & 193240 & 44538 & 950 & 45488 & $1: 4.24$ \\
\hline $\mathbf{5}$ & Quinolphos 25EC & 186.73 & 1000 & 186730 & 44538 & 2520 & 47058 & $1: 3.96$ \\
\hline $\mathbf{6}$ & Carbosulfan 20EC & 178.43 & 1000 & 178430 & 44538 & 1383 & 45921 & $1: 3.88$ \\
\hline $\mathbf{7}$ & Neem Oil 0.3EC & 169.67 & 1000 & 169670 & 44538 & 1130 & 45668 & $1: 3.71$ \\
\hline $\mathbf{8}$ & Control & 90.32 & 1000 & 90320 & 44538 & 00 & 44538 & $1: 2.02$ \\
\hline
\end{tabular}

Insecticides like Chlorantroniliprole and Spinosad can be suitably incorporated in pest management schedule against shoot and fruit borer as an effective tool as their recommended field doses are very low.

\section{References}

Ayyanar, S., Pillai, M.A.K. and Murugeesan, N. 2014. Studies on the Seasonal Influence on the Occurrence of Shoot and Fruit Borer (Leucinodes orbonalis Guenee) in Brinjal (Solanum melongena L.) Var. Kkm-1. Indian Journal of Applied Research, 4 (8): 1-7

Das, S., Patel, J.I. and Wazire, J.I. 2014. Seasonal abundance of brinjal shoot and fruit borer, Leucinodes orbonalis Guenee, in relation to weather parameters. Environmental Biotech Journal, 20 (01): 73-76.

Gangwar, R.K. and Singh, D.V. 2014. Study 
on Insect Pest Succession of Brinjal Crop Ecosystem in Western Region of Uttar Pradesh, India. Journal of Biology, Agriculture and Healthcare, 4 (17): 2224-3208.

Kalawate, A. and Dethe, M.D. 2012. Bioefficacy study of biorational insecticide on brinjal. Journal of Biopesticides, 5(1): 75-80.
Shukla, A. and Khatri, S.N. 2010. Incidence and abundance of brinjal shoot and fruit borer Leucinodes orbonalis Guenee. The Bioscan, 5 (2): 305-308.

Sinha, S.R., Gupta, R.K., Gajbhiye, V.T. and Vishwanath, 2010. Bioefficacy and persistence of indoxacarb on Solanum melongena. Annuals of Plant Protection Sciences, 18(1):278-280.

\section{How to cite this article:}

Saurabh Kumar Tyagi, Sharanappa and Ashwani Kumar. 2019. Seasonal Incidence, Comparative Field Efficacy of Chemical Insecticides and their Economics for Management Brinjal Shoot and Fruit Borer Leucinodes orbanalis (guenee). Int.J.Curr.Microbiol.App.Sci. 8(03): 54-58. doi: https://doi.org/10.20546/ijcmas.2019.803.008 